\title{
Atrazine affects kidney and adrenal hormones (AHs) related genes expressions of rare minnow (Gobiocypris rarus)
}

\author{
Lihua Yang, Jinmiao Zha, Wei Li, Zhaoli Li, Zijian Wang* \\ State Key Laboratory of Environmental Aquatic Chemistry, Research Center for Eco-Environmental Sciences, Chinese Academy of Sciences, Shuangqing Road 18, \\ P.O. Box 2871, Beijing 100085, China
}

\section{A R T I C L E I N F O}

\section{Article history:}

Received 10 July 2009

Received in revised form 5 September 2009

Accepted 10 September 2009

\section{Keywords}

Atrazine

Histopathology

Adrenal hormones disruption

Rare minnow (Gobiocypris rarus)

\begin{abstract}
A B S T R A C T
Atrazine, one of the most widely used herbicides, has been proved to interfere with sexual hormones. However few studies have considered the effects of atrazine on adrenal hormones (AH). In this study, rare minnow (Gobiocypris rarus) was exposed to $0,3,10,33,100$ and $333 \mu \mathrm{g} / \mathrm{l}$ atrazine for 28 days. The histopathology of kidney and gill was examined and the expressions of AHs-related genes including $\mathrm{Na}^{+}, \mathrm{K}^{+}$-ATPase, glucocorticoid receptor ( $\left.g r\right)$, heat shock protein 70 ( $\left.h s p 70\right)$, and heat shock protein 90 ( $h s p 90)$ in kidney and gill were quantitatively determined. Histopathological observation revealed obvious lesions in gill including hyperplasia, necrosis in epithelium region, aneurysm and lamellar fusion at concentrations as low as $10 \mu \mathrm{g} / \mathrm{l}$. The observed lesions in kidney included extensive expansion in the lumen, degenerative and necrotic changes of the tubular epithelia, shrinkage of the glomerulus as well as increase of the Bowman's space at concentrations as low as $10 \mu \mathrm{g} / \mathrm{l}$. The expressions of $\mathrm{Na}^{+}, \mathrm{K}^{+}$-ATPase, $g r, h s p 70$ and $h s p 90$ in the kidney of females were significantly decreased at all concentrations. For males, the expressions of $h s p 90$ in the kidney of all treated groups were significantly down-regulated, while gr at all concentrations and $h s p 70$ at $10,33,100 \mu \mathrm{g} / \mathrm{l}$ were significantly up-regulated. However in the gill, the expressions of these genes were not significantly different from the control. These results indicated that exposure to atrazine caused impairments of kidney and gill of fish at environmental related concentrations. Histopathological lesions could partly attribute to the changes of the expressions of AHs-related genes in kidney. We concluded also that atrazine is a potential AHs-disruptor and AHs-related genes in kidney of fish could be used as sensitive molecular biomarkers.
\end{abstract}

(C) 2009 Elsevier B.V. All rights reserved.

\section{Introduction}

Recent studies indicated that the hypothalamic-pituitaryadrenal (HPA) axis was also an important target of endocrine disruptors (Bisson and Hontela, 2002; Moore et al., 2003). The maintaining of HPA axis is directly bound up with adrenal hormones (AHs) including cortical and medullary hormones. In mammals, there are two distinct corticosteroids: glucocorticoid involved in metabolism and growth, and mineralocorticoid regulating the movement of ions and water. However, in fish both glucocorticoid and mineralocorticoid functions were served by a glucocorticoid (cortisol) (Wendelaar Bonga, 1997). Although in some teleosts the existence of MR like gene has been proved (Colombea et al., 2000), recent researches of McCormick et al. (2008) showed that the putative GR blocker RU486 inhibited cortisol induced increases in salinity tolerance, $\mathrm{Na}^{+}, \mathrm{K}^{+}$-ATPase activity and mRNA transcrip-

\footnotetext{
* Corresponding author. Tel.: +86 10 62849140; fax: +861062929140. E-mail address: wangzj@rcees.ac.cn (Z. Wang).
}

tion, whereas the putative MR blocker spironolactone had no effect. These results also suggested a direct connection $\backslash$ GR signaling and $\mathrm{Na}^{+}, \mathrm{K}^{+}$-ATPase. hsp70 and hsp90, molecular chaperons of GR, play an important role in GR signaling and functional execution of cortisol. $\mathrm{Na}^{+}, \mathrm{K}^{+}$-ATPase is widely used as a marker for ion regulatory changes (de Renzis and Bornancin, 1984) and has been demonstrated correlated with the development of salinity tolerance in fish (Waring and Moore, 2004).

Atrazine (2-chloro-4-ethylamino-6-isopropyl-amino-striazine), one of the most widely used herbicides for the control of weeds and grasses in corn, sorghum and sugarcane, could enter the aquatic ecosystems carried by runoff from agricultural fields (Huber, 1993). Atrazine has been detected in rivers at concentrations up to $108 \mu \mathrm{g} / \mathrm{l}$ in North America (USEPA, 2002), and the highest level occurred in runoff water at concentration as high as $275 \mu \mathrm{g} / \mathrm{l}$ (Huber, 1993). In China, atrazine concentrations exceeding the standards for drinking-water $(3 \mu \mathrm{g} / \mathrm{l})$ have also been reported in Guanting reservoir (Ren et al., 2002) and Taihu Lake (Dong et al., 2006). Because of its high water solubility and stability, atrazine could be ubiquitous in waters for a long time and cause ecotoxicity. 
Previous studies have shown that atrazine could affect the reproductive system of wild animals. For example, its effects on the reproduction of copepods (Hincapie et al., 2005) and metamorphosis and sex differentiation of Xenopus laevis (Freeman and Rayburn, 2004) were observed. Cooper et al. (2000) proved that atrazine could exert influence on the ovarian function in rats through disrupting the neuroendocrine control of HPG axis. Waring and Moore (2004) reported that atrazine could alter plasma ion levels and $\mathrm{Na}^{+}, \mathrm{K}^{+}$-ATPase activity in gill of Atlantic salmon (Salmo salar), therefore cause disturbance of osmoregulation. Moreover, changes of the secretion of cortisol were found while adrenocortical steroidogenic cells of rainbow trout (Oncorhynchus mykiss) exposed to atrazine (Bisson and Hontela, 2002). Osmoregulation, one of the most important functions of the HPA axis, was mainly accomplished through gill and kidney in fish. However, multi-gene effects of atrazine on osmoregulation in gill and especially kidney of fish have not been throughout studied.

Rare minnow (Gobiocypris rarus) is considered to be an appropriate species for the assessment of endocrine disrupting chemicals due to its small size, ease of culture, short life cycle and prolific egg production with high fertilization and hatching rates (Zha et al., 2007; Zhang et al., 2008). Effects on the hypothalamic-pituitary-gonad (HPG) and hypothalamic-pituitary-thyroid (HPT) axis by environment pollutants have been demonstrated in rare minnow (Zha et al., 2007; Zhang et al., 2008; Li et al., 2009).

In this study, the effects of atrazine on osmoregulation of adult rare minnow were evaluated at environmentally relevant concentrations. Therefore, the objective of our studies was to evaluate the relative expressions of selected genes concerning GR signaling ( $g r$, hsp70, hsp90) and ions regulation $\left(\mathrm{Na}^{+}, \mathrm{K}^{+}\right.$-ATPase $)$in gill and kidney; to examine histopathological lesions of gill and kidney.

\section{Materials and methods}

\subsection{Test fish and culture conditions}

Rare minnow has been maintained in our laboratory for more than 6 years. The brood stock was kept in flow-through system with dechlorinated tap water and subjected to a 16:8 h of light:dark at $25 \pm 1{ }^{\circ} \mathrm{C}$. The brood stock was fed newly hatched brine shrimp (Artemia nauplii) twice and granule food (TetraMin, Tetra Werke, Melle, Germany) once a day.

\subsection{Chemicals}

Atrazine (purity > 98\%) and acetone were purchased from Sigma (Chemical Co., USA).

\subsection{Experimental protocol}

Sexually mature fish (10 months old) were the offspring from the same pair of brood stock and were randomly divided into six groups of thirty each. The average body weights and body lengths were $1.2 \pm 0.4 \mathrm{~g}$ and $42.3 \pm 3.7 \mathrm{~mm}$, respectively. Male or female fish were identified by examining both the relative distance between the tip of abdomen fin and the starting point of stern fin and also the shape of the abdomen (Wang, 1992). Fish were kept under flow-through conditions at $25 \pm 1{ }^{\circ} \mathrm{C}$ with a photoperiod of $16: 8 \mathrm{~h}$ (light:dark), and generally fed with a commercial granule food (Trea, Germany) at a rate of $0.1 \%$ body weight per day and newly hatched brine shrimp (Artemia nauplii) two times daily. Wastes and residues were removed daily and the test equipment and chambers were cleaned once a week.

After accumulating for 2 weeks, fish were exposed to various concentrations $(3,10,33,100,333 \mu \mathrm{g} / \mathrm{l})$ of atrazine. A vehicle treatment containing a combination of acetone served as a control. The ratio of vehicle to water was $1: 100,000(\mathrm{v} / \mathrm{v})$. The stock solutions were prepared every 3 days in high-performance liquid chromatography-grade acetone and dosed to glass mixing vessels by means of a peristaltic pump at a rate of $1 \mathrm{ml} / \mathrm{min}$. Then, the solutions were diluted with dechlorinated tap water flowing to the mixing vessels at a rate of $41 / \mathrm{h}$, which ensured the retention time shorter than $4 \mathrm{~h}$ or the renew times more than 6 in a day.

Fish were sacrificed after 28 days of exposure. Gill and kidney from four males and four females in each group were fixed in Bouin's solution (71\% saturated picric acid, $24 \%$ formaldehyde, $5 \%$ glacial acetic acid; Sigma-Aldrich, USA), and tissues from the rest of male and female rare minnow were flash-frozen in liquid nitrogen, and stored at $-80^{\circ} \mathrm{C}$.

\subsection{Histopathology}

After $24 \mathrm{~h}$ gill and kidney samples fixed in Bouin's solution were transferred to $70 \%$ ethanol and processed routinely according to standard histological methods and embedded in paraffin wax as described by Wolf et al. (2004). The sections were cut at 3-4 $\mu \mathrm{m}$ and stained with hematoxylin and eosin, and the section of the paraffin blocks were analyzed on a Axioskop 2 mot plus optical microscope (Zeiss, Germany) and digitized with a AxioCam digital camera (Zeiss) using the Application Suite software AxioVision Rel. 4.5 (Zeiss). Width of secondary lamella and epidermal thickness of gill and renal tubules were measured as described by Kokolakis et al. (2008).

\subsection{Preparation of $c D N A$ from gill and kidney of rare minnow}

Total RNA was isolated using SV Total RNA Isolation System (with DNase I, promega, USA), and the RNA samples were dissolved in ribonuclease-free water and stored at $-80^{\circ} \mathrm{C}$.

Subsequently, the reverse transcription reaction mixtures containing of $10 \mu \mathrm{l}$ total RNA, $2 \mu \mathrm{l}(0.05 \mu \mathrm{g} / \mu \mathrm{l})$ of Oligo(dT) ${ }_{15}$ were heated to $70^{\circ} \mathrm{C}$ for $5 \mathrm{~min}$ and quickly chilled on ice for $30 \mathrm{~s}$, then $50 \mathrm{mM}$ Tris- $\mathrm{HCl}$ buffer ( $\mathrm{pH}$ 8.3), $75 \mathrm{mM} \mathrm{KCl}, 10 \mathrm{mM}$ dithiothreitol, $3 \mathrm{mM} \mathrm{MgCl}_{2}, 2 \mathrm{mM}$ deoxynucleotide triphosphate (10 $\mathrm{mM}$ each), 40 units of RNAasin (RNAase inhibitor; Promega), and $200 \mathrm{U}$ of Moloney Murine Leukemia Virus Reverse Transcriptase (Promega) were added to a total volume of $25 \mu \mathrm{l}$ and incubated for $1 \mathrm{~h}$ at $37^{\circ} \mathrm{C}$. Thereafter, the reaction mixture was heated to $70^{\circ} \mathrm{C}$ for $10 \mathrm{~min}$ to inactivate the reverse transcription. The samples were stored at $-20^{\circ} \mathrm{C}$ until analysis.

\subsection{Quantitation by real-time $P C R$}

Real-time PCR was performed in Mx3005P real-time quantitative polymerase chain reaction system (Stratagene, USA) in a total volume of $25 \mu \mathrm{l}$ comprised $1 \mu \mathrm{l}$ cDNA, $12.5 \mu \mathrm{l}$ Brilliant II SYBR Green QPCR master mix $(2 \times$, Stratagene, USA), $300 \mathrm{nM}$ forward primer and $300 \mathrm{nM}$ reverse primer, and diethyl pyrocarbonatetreated water. The primer pairs used for real-time PCR were shown in Table 1 . The cycling conditions used were: an initial denaturation step of $95^{\circ} \mathrm{C}$ for $10 \mathrm{~min}$, followed by 40 cycles of $95^{\circ} \mathrm{C}$ for $30 \mathrm{~s}$, $57^{\circ} \mathrm{C}$ for $40 \mathrm{~s}$ and $72^{\circ} \mathrm{C}$ for $30 \mathrm{~s}$, and the last cycle of $95^{\circ} \mathrm{C}$ for $30 \mathrm{~s}$, $57^{\circ} \mathrm{C}$ for $30 \mathrm{~s}$ and $72{ }^{\circ} \mathrm{C}$ for $60 \mathrm{~s}$ for dissociation curve. Exclusive peak was observed for each amplification, indicating that there was no amplification of untargeted gene.

All the samples were analyzed twice and each reaction was performed in triplicate. The mean values were used for calculations of mRNA expressions. Firstly fold changes of $\mathrm{Na}^{+}, \mathrm{K}^{+}$-ATPase, gr, hsp70 and $h s p 90$ mRNA expressions were calculated using a delta-delta $\mathrm{Ct}$ method, and were normalized for $\beta$-actin mRNA expression. The 
Table 1

Sequences of primers used for RT-PCR.

\begin{tabular}{|c|c|c|c|c|}
\hline Genes & Accession no. & & Primer sequences (from $5^{\prime}$ to $3^{\prime}$ ) & Product size (bp) \\
\hline$\beta$-Actin & DQ539421 & $\begin{array}{l}\text { Forward } \\
\text { Reverse }\end{array}$ & $\begin{array}{l}\text { CAGGGCGTGATGGTGGGGAT } \\
\text { GGTTGGCTTTGGGGTTGAG }\end{array}$ & 226 \\
\hline $\mathrm{Na}+, \mathrm{K}+$-ATPase & FJ527618 & $\begin{array}{l}\text { Forward } \\
\text { Reverse }\end{array}$ & $\begin{array}{l}\text { ACATTGGTGTGGCTATGGG } \\
\text { TTGAGGCAAAGTTGTCGTC }\end{array}$ & 87 \\
\hline$g r$ & FJ410931 & $\begin{array}{l}\text { Forward } \\
\text { Reverse }\end{array}$ & $\begin{array}{l}\text { GAGAACTCCAGCCAGAACTG } \\
\text { CCACGCTCAGAGATTTATTCAC }\end{array}$ & 126 \\
\hline hsp70 & FJ410933 & $\begin{array}{l}\text { Forward } \\
\text { Reverse }\end{array}$ & $\begin{array}{l}\text { CTCATTGGGCGACGATTT } \\
\text { CCTTTGTATTCAACCTGGACCT }\end{array}$ & 110 \\
\hline hsp90 & FJ827029 & $\begin{array}{l}\text { Forward } \\
\text { Reverse }\end{array}$ & $\begin{array}{l}\text { CACTCTCAGTTCATCGGTTACC } \\
\text { TCСTTGACСTTCTTCTTCCTC }\end{array}$ & 297 \\
\hline
\end{tabular}

final data of relative gene expressions was presented as log base 2 of fold change.

\subsection{Statistical analysis}

All quantitative data are expressed as means \pm SEM. Statistical analysis of variance was performed with one-way ANOVA, SPSS (version 13.0; USA), and levene test of homogeneity of variance and LSD $t$-test were used. A probability of $p<0.05$ was considered statistically significant.

\section{Results}

\subsection{Histopathology}

General structure of the gill from control exhibited well-shaped primary lamellae with cartilaginous tissue at the bottom and sec- ondary lamellae (Fig. 1A and D). Each filament has two rows of secondary lamellae which are made up of two sheets of epithelium delimited by many pillar cells. One-way ANOVA revealed a significant increase of the epidermal thickness in gill of females at $10 \mu \mathrm{g} / \mathrm{l}(12.49 \pm 1.81 \mu \mathrm{m}), 100 \mu \mathrm{g} / \mathrm{l}(12.84 \pm 1.58 \mu \mathrm{m})$ and $333 \mu \mathrm{g} / \mathrm{l}$ $(13.17 \pm 1.66 \mu \mathrm{m})$ compared with the control $(9.77 \pm 1.67 \mu \mathrm{m})$ $(p<0.05)$. Width of the secondary lamellae was also increased in males (from $7.48 \pm 0.98$ to $14.21 \pm 1.77 \mu \mathrm{m}$ ) and females $(8.83 \pm 0.87$ to $13.68 \pm 2.16 \mu \mathrm{m})$ when exposed to atrazine at $333 \mu \mathrm{g} / \mathrm{l}$. No histopathological lesions were observed in the gill of males or females exposed to atrazine at $3 \mu \mathrm{g} / \mathrm{l}$. Gill of females exposed to $10 \mu \mathrm{g} / \mathrm{l}$ atrazine (Fig. 1B) showed club-shaped cartilaginous tissue and hyperplasia in the secondary lamellae, and the most severe changes occurred at $333 \mu \mathrm{g} / \mathrm{l}$ group (Fig. 1C) including club-shaped cartilaginous tissue, hyperplasia, aneurysm, and necrosis in epithelium region. Edema and fusion of the secondary lamellae were noted in gill of male fish exposed to

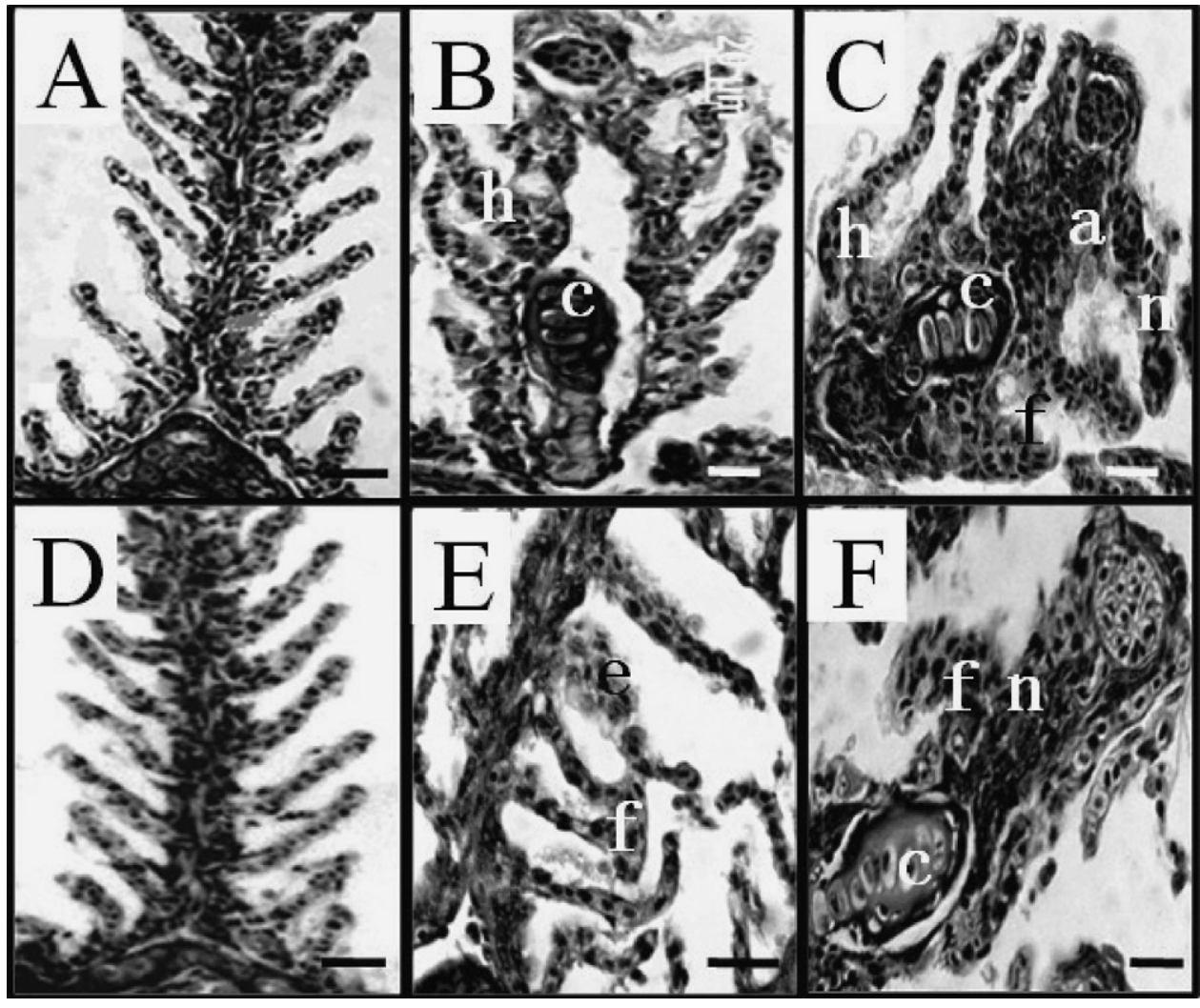

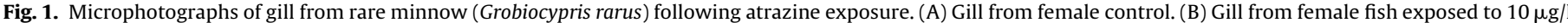

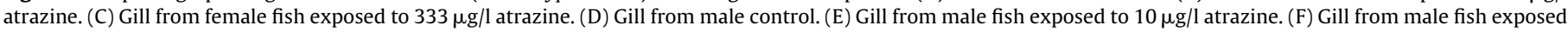

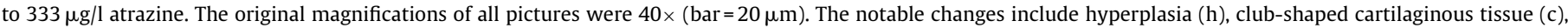
edema (e), aneurysm (a), fusion of the secondary lamellae (f) and epithelial necrosis (n). 


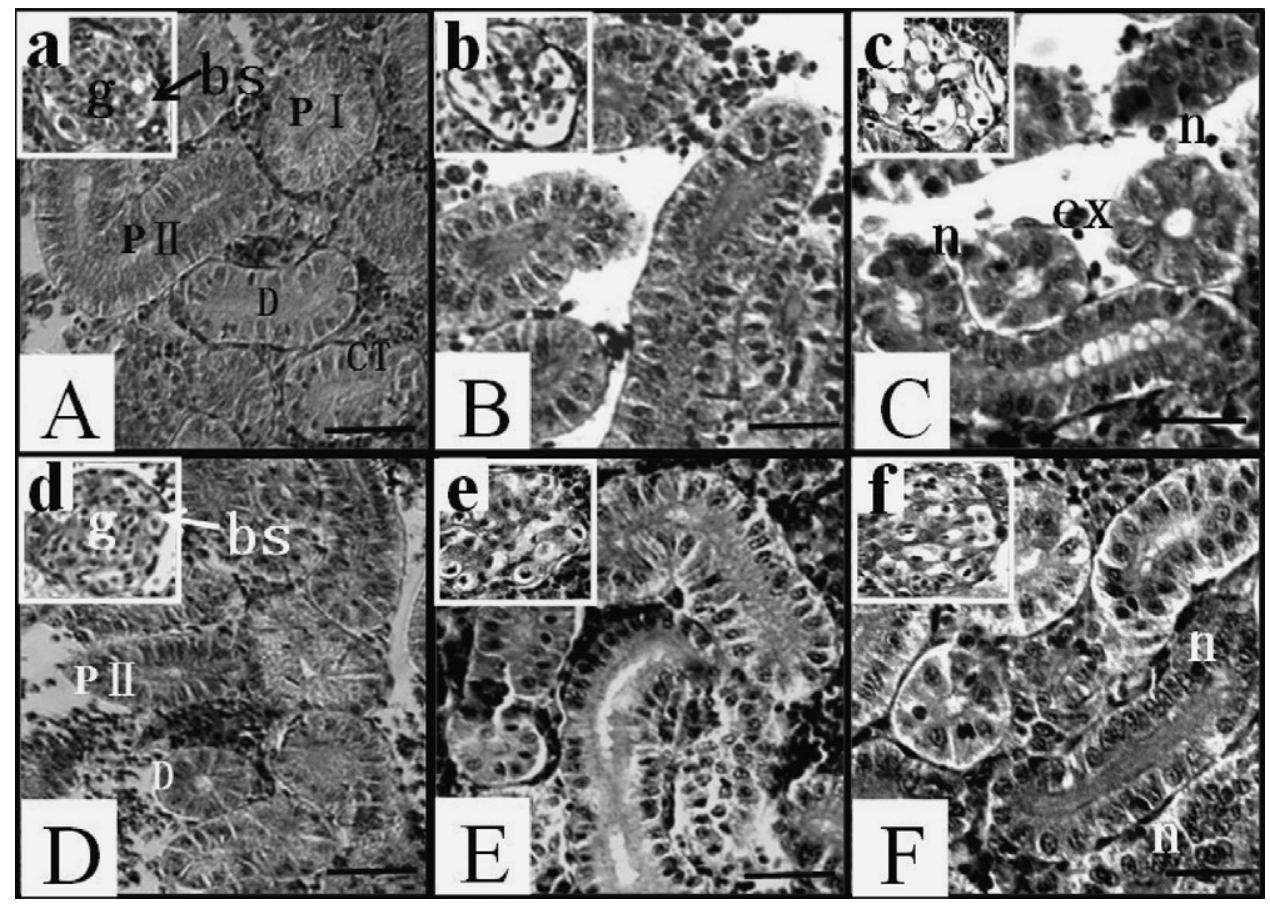

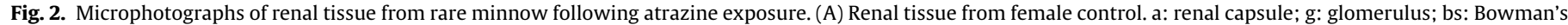

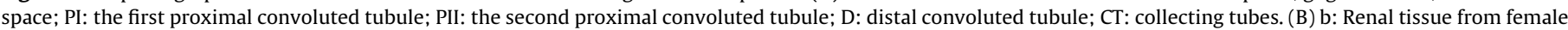

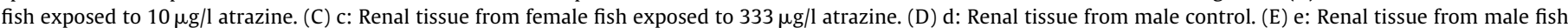

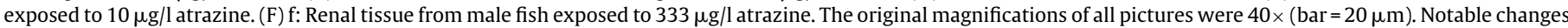

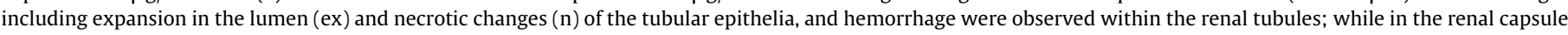
a dose dependent shrinkage of glomerulus and increase of the Bowman's space was observed.

$10 \mu \mathrm{g} / \mathrm{l}$ atrazine (Fig. 1E). Besides, club-shaped cartilaginous tissue, fusion of secondary lamellae and necrosis in epithelium region (Fig. 1F) were observed when males were exposed to $333 \mu \mathrm{g} / \mathrm{l}$ atrazine.

Normal renal tissue was composed of numerous renal corpuscles with well-developed renal capsule and an intricate system of tubules which could be segmented into the first and second proximal convoluted tubule (P I, P II), distal convoluted tubule (D) and collecting tubes $(\mathrm{CT})$. The wall of kidney tubules was lined with large, clear columnar epithelial cells having oval or rounded basal nuclei (Fig. 2A and D). The renal capsule is composed of a glomerulus surrounded by Bowman's capsule, and between the parietal and the visceral epithelium of the glomerulus lays the Bowman's space (Fig. 2a and d). Considerable increases in the lumen of distal convoluted tubule (from $4.73 \pm 0.89$ to $7.04 \pm 1.26 \mu \mathrm{m}$ ) and collecting tubes (from $9.55 \pm 1.45$ to $14.27 \pm 0.49 \mu \mathrm{m}$ ) and decrease in the epidermal thickness of distal convoluted tubule (from $9.55 \pm 1.45$ to $14.27 \pm 0.49 \mu \mathrm{m}$ ) were observed in female fish exposed to atrazine
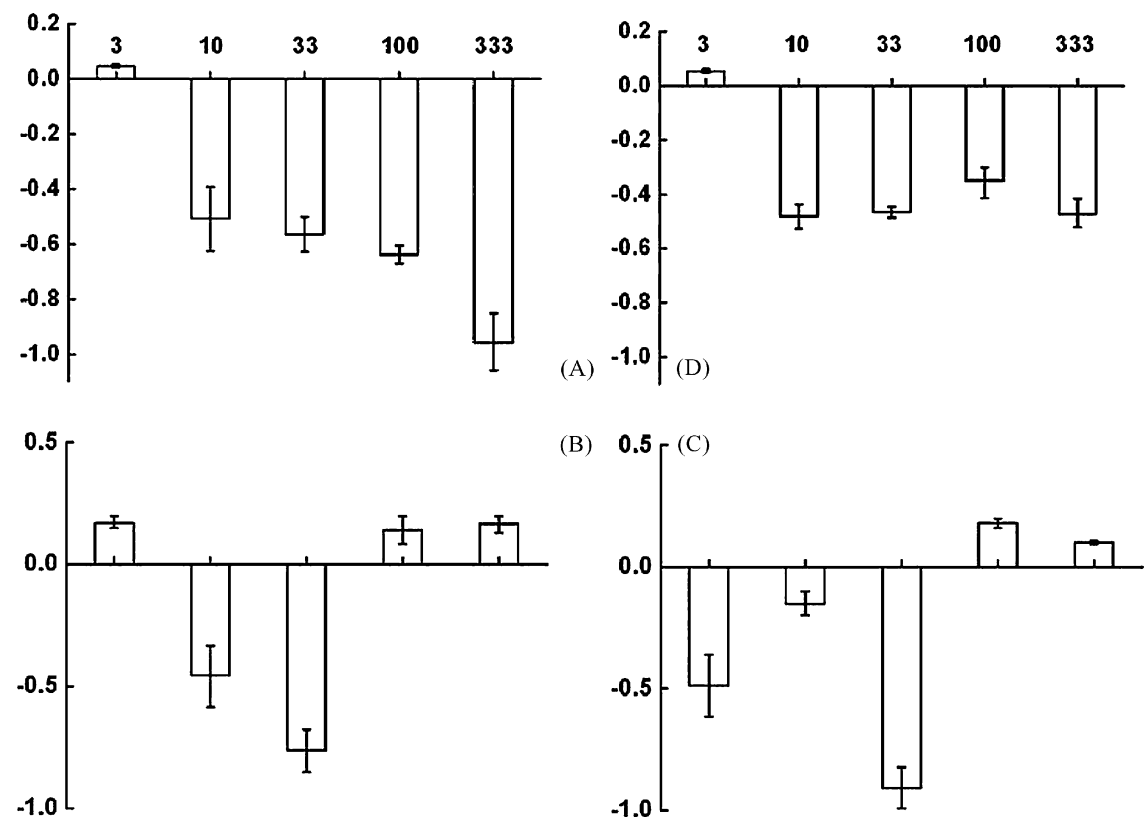

Fig. 3. Expressions of $\mathrm{Na}^{+}, \mathrm{K}^{+}$-ATPase, gr, $h s p 70$ and $h s p 90$ mRNA in gill of female rare minnow (Grobiocypris rarus). (A) Na+ $\mathrm{K}^{+}$-ATPase, (B) gr, (C) $h s p 70$, (D) $h s p 90$. 

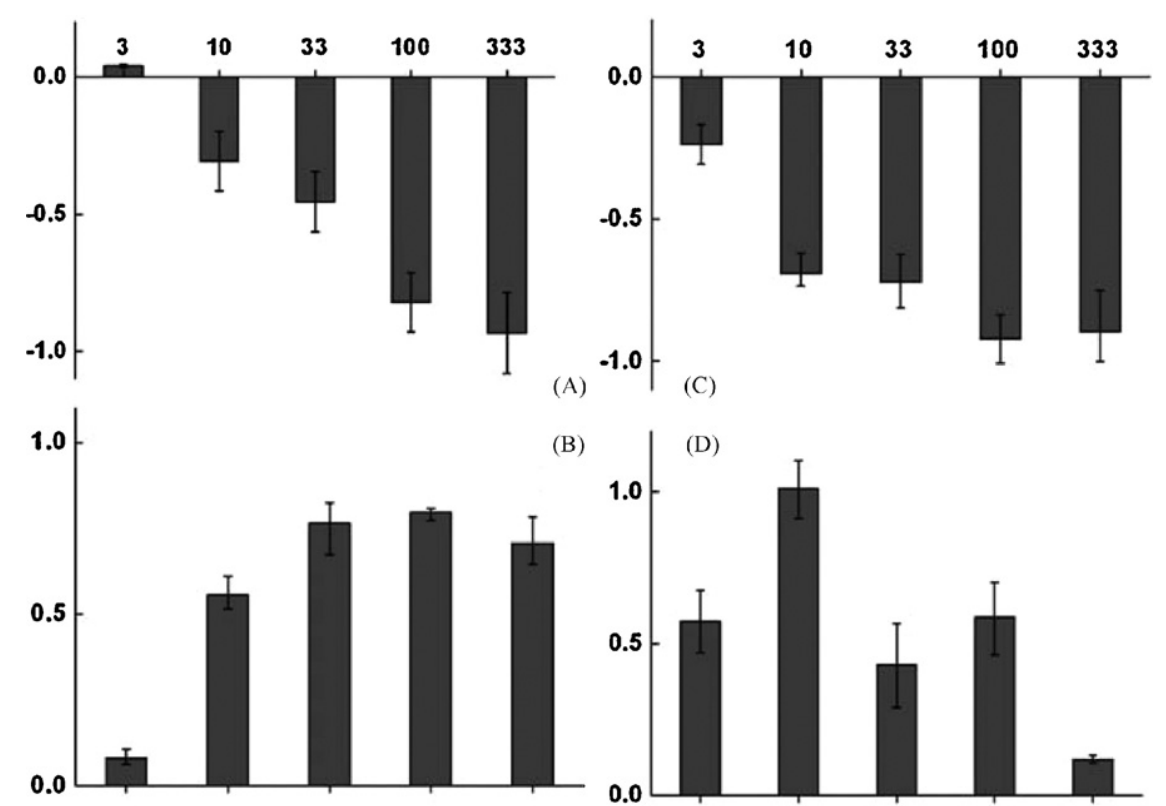

Fig. 4. Expressions of $\mathrm{Na}^{+}, \mathrm{K}^{+}$-ATPase, gr, $h s p 70$ and $h s p 90$ mRNA in gill of male rare minnow (Grobiocypris rarus). (A) Na ${ }^{+} K^{+}-A T P a s e,(\mathrm{~B}) \mathrm{gr}$, (C) $h s p 70$, (D) $h s p 90$.

at $333 \mu \mathrm{g} / \mathrm{l}$ compared with the control $(p<0.05)$. No significant change of the epidermal thickness and lumen was noticed in males. Micrographic revealed no obvious morphological change in the kidney of males or females exposed to atrazine at $3 \mu \mathrm{g} / \mathrm{l}$. The glomerulus of female fish exposed to $10 \mu \mathrm{g} / \mathrm{l}$ atrazine started to shrink and resulted in a mild increase of the Bowman's space (Fig. $2 \mathrm{~b}$ and e). Exposure of $333 \mu \mathrm{g} / \mathrm{l}$ atrazine resulted in expansion in the lumen of tubules, necrotic changes of the tubular epithelia in females (Fig. 2C) and necrosis of the tubular epithelia in males (Fig. 2F). Besides the shrink of the glomerulus and increase of the Bowman's space become more severe in renal tissue from both male and female fish (Fig. $2 \mathrm{c}$ and f).

\subsection{Results of real-time PCR}

The expressions of $\mathrm{Na}^{+}, \mathrm{K}^{+}$-ATPase, gr, hsp70 and $h s p 90$ in gill and kidney of males and females were determined after 28 days exposure to atrazine. The data was presented as the value of log base 2 of fold change. The calculated results of all control groups were 0 (not shown in the figures), and the variability of all gene expressions was within $\pm 15 \%$.

Expressions of gill $\mathrm{Na}^{+}, \mathrm{K}^{+}$-ATPase showed dose dependent decline in both male and female fish compared to the control, but not statistically significant (Figs. 3 and 4). No significant change was observed in other genes determined in gill (Figs. 3 and 4).
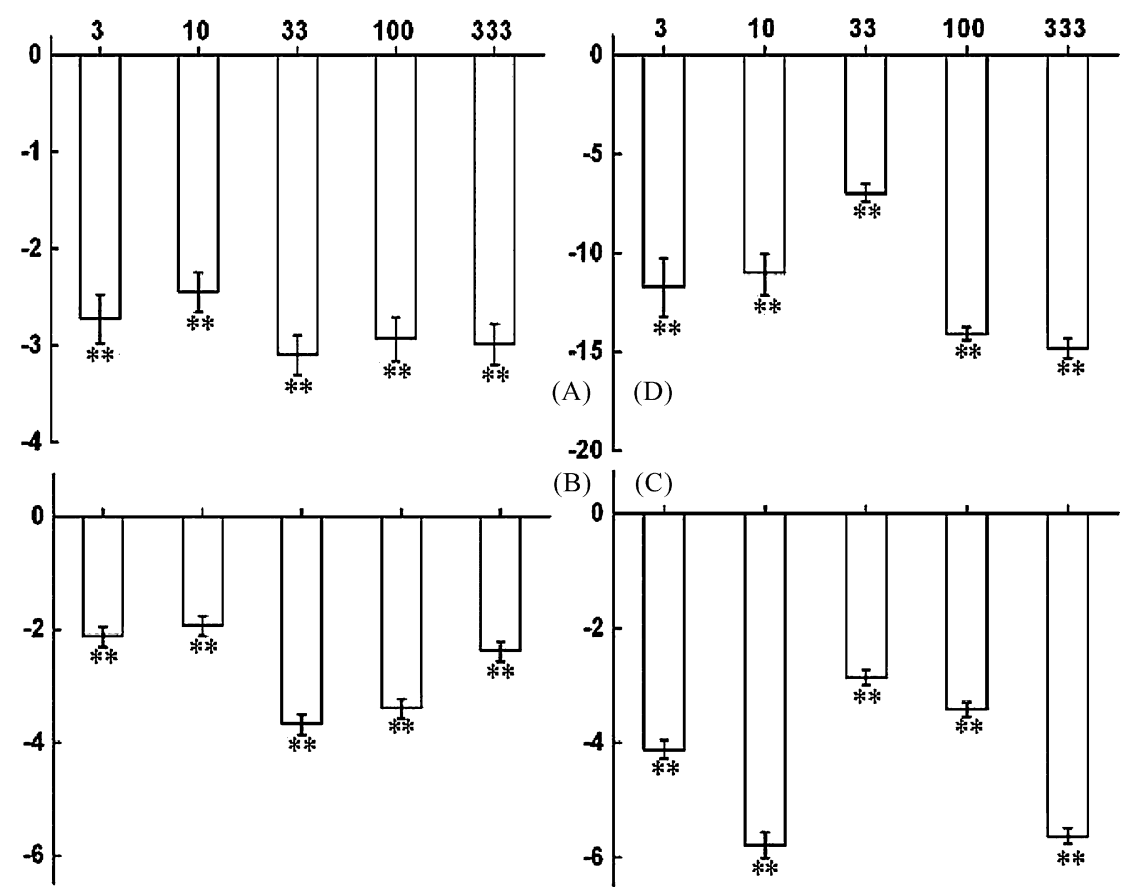

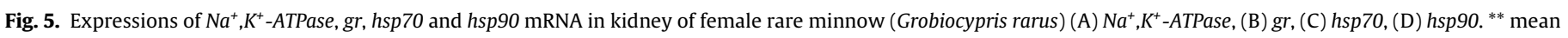
significantly different from the control at 0.01 level. 

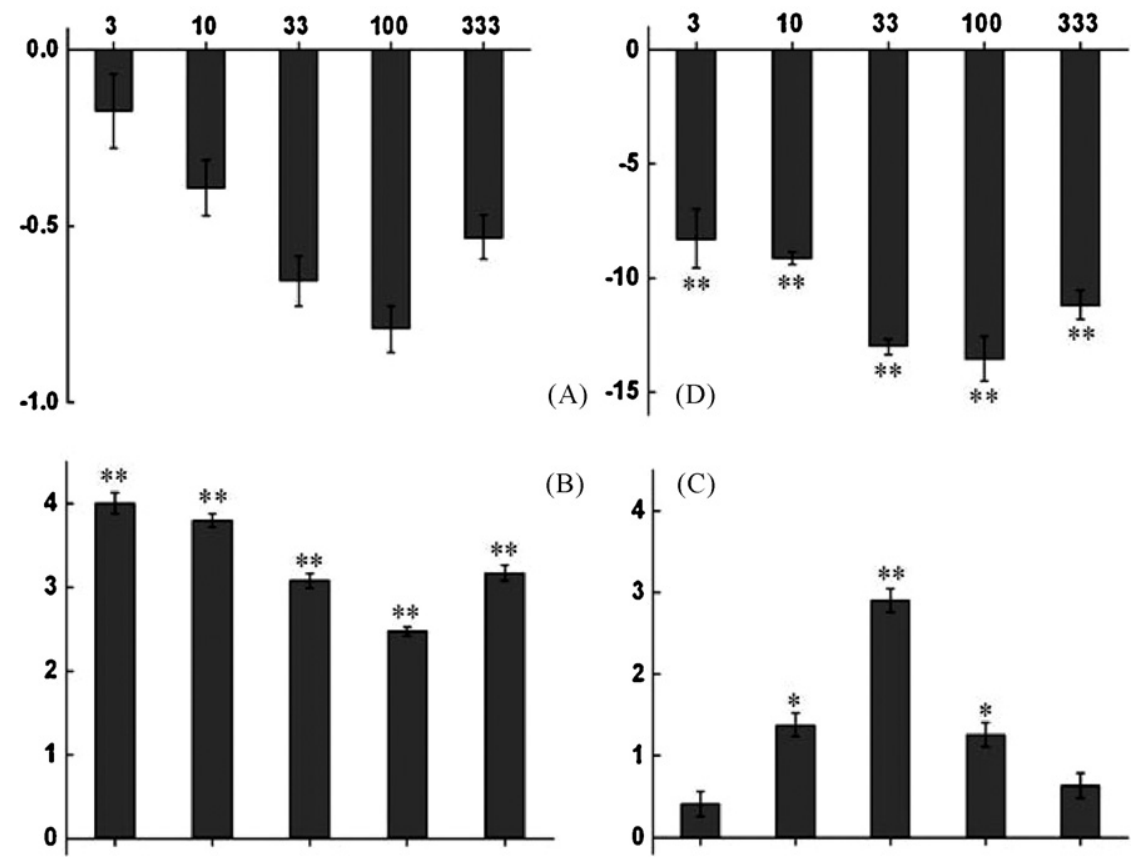

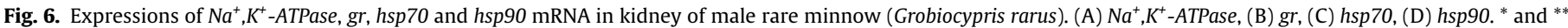
mean significantly different from the control at 0.05 and 0.01 level, respectively.

In kidney of female rare minnow (Fig. 5), the expressions of these genes were all significantly decreased compared to the control $(p<0.05)$. The expressions of $h s p 90$ in the kidney of males were significantly down-regulated $(p<0.05)$ while $g r$ and $h s p 70$ were significantly induced $(p<0.05)$ (Fig. 6).

\section{Discussion}

Histopathological changes of gill and kidney were examined to investigate the effects of atrazine on the major osmoregulatory organs, gill and kidney of rare minnow in this study. Significant changes including increase of epidermal thickness and lamellar width, fusion of secondary lamellae, hyperplasia, club-shaped cartilaginous tissue, aneurysm, and necrosis in epithelium region were found in the gill of females exposed to atrazine at and higher than $10 \mu \mathrm{g} / \mathrm{l}$. Besides, edema, increased width and fusion of the secondary lamellae and epithelial necrosis were found in males exposed to atrazine at and higher than $10 \mu \mathrm{g} / \mathrm{l}$. The lesions became more severe with the increase of the concentration of atrazine. The appearance of club-shaped cartilaginous tissue may indicate that the lamellae become fragile thus more support was needed. Previous study suggested edematous changes in the gill were most probably due to the increase in capillary permeability (Roberts, 1978). Hyperplasia was considered as a protective mechanism from environmental irritant by decreasing the respiratory surface and increasing the toxicant-blood diffusion distance (Meissner and Diamandopoulos, 1977), and its intensification could result in the thickness of epithelial layers, which could be supported by the increases of epithermal thickness and lamellar width, and the fusion of adjacent secondary lamellae which was also observed in the present study. Such lesions have also been observed in gill of rainbow trout (Velisek et al., 2006) and common carp (Cyprinus carpio) (Cengiz, 2006). Aneurysm in the second lamellae was supposed to be relevant to the disturbance of blood flow (Alazemi et al., 1996), and Cengiz (2006) found the same result when common carp was exposed to deltamethrin. According to Cengiz (2006) epithelial necrosis was a direct response to the stimulation of environmen- tal pollutants. Same results have been found in the gill of rainbow trout treated with cypermethrin (Velisek et al., 2006). Thus, all the lesions found in the present study would probably inhibit the respiratory, secretory and excretory functions in the gill of rare minnow. These results suggested that exposure to atrazine at and higher than $10 \mu \mathrm{g} / \mathrm{l}$ could result in apparent histopathological damages on gill of rare minnow.

There was no obvious morphological change in the kidney of males or females exposed to atrazine at $3 \mu \mathrm{g} / \mathrm{l}$. The glomerulus started to shrink thus resulting in a mild increase of the Bowman's space in renal tissue at $10 \mu \mathrm{g} / \mathrm{l}$. Lesions became more severe at the highest concentration $(333 \mu \mathrm{g} / \mathrm{l})$. A considerable shrinkage of the glomerulus resulted in remarkable increase of the Bowman's space; besides, necrosis of the epithelia was found in the tubules. Both statistical analysis and micrographic observations revealed an expansion of the renal tubules in females. According to Schwaiger et al. (2000) and Zaroogian et al. (2001), the expansion of the kidney tubules was probably due to the accumulation of eosinophilic material which was proposed to be VTG. The accumulation of eosinophilic material may ultimately result in blockage of the renal tubules and impairment of kidney functions. The decrease of epidermal thickness indicated a degeneration of the tubular epithelia in females. Degenerative and necrotic changes in renal tubules have been reported in ethynylestradiol treated rare minnow (Zha et al., 2007) and common carp (Schwaiger et al., 2000). The shrinkage in the glomerulus and increase in Bowman's space indicated alterations in excretion of the kidney in atrazine treated rare minnow. Roy and Bhattacharya (2006) have reported similar observations in the kidney of spotted murrel (Channa punctatus) after exposure to arsenic. The micrography also showed that lesions of renal corpuscles are mere more severe in females than in males. This was consisted with the statistical results which revealed more significant changes in renal tubules of females.

All morphological changes indicated that exposure to environmentally relevant concentrations of atrazine caused destructive effects in gill and kidney tissues which may result in severe 
functional problems, ultimately leading to the death of fish. Therefore findings in this study would be useful for detecting endocrine disrupting activity with the rare minnow in laboratory studies as well as in the field.

Real-time PCR assays were established to evaluate the relative expressions of $\mathrm{Na}^{+}, \mathrm{K}^{+}$-ATPase, gr, hsp70 and $h s p 90$ mRNA in gill and kidney when adult fish were exposed to environmentally relevant concentrations of atrazine. With the advances in molecular approaches, the application of toxicogenomics could be a powerful tool for evaluating the effects and discovering molecular mechanisms underlying toxic response (Nie et al., 2006). Most studies involved in osmoregulation have been focused on the gill (Waring and Moore, 2004; Richards et al., 2003). However, the molecular response in kidney, another important osmoregulatory organ, has hardly been reported.

$\mathrm{Na}^{+}, \mathrm{K}^{+}$-ATPase is widely used as a marker for ion regulatory changes. Gill $\mathrm{Na}^{+}, \mathrm{K}^{+}$-ATPase activity and mRNA abundance increased in salinity acclimation process in rainbow trout (Richards et al., 2003) and Atlantic salmon (Moore et al., 2003; Waring and Moore, 2004). Waring and Moore (2004) have reported a dose dependent decrease of gill $\mathrm{Na}^{+}, \mathrm{K}^{+}$-ATPase activity in Atlantic salmon exposed to atrazine for 7 days. In this study, similar dose dependent decreases were also found in $\mathrm{Na}^{+}, \mathrm{K}^{+}$-ATPase mRNA expressions in the gill of rare minnow, but not statistically significant. Nieves-Puigdoller et al. (2007) also reported a nonsignificant decrease of gill $\mathrm{Na}^{+}, \mathrm{K}^{+}$-ATPase activity in Atlantic salmon exposed to atrazine for 21 days. It is possible that compensatory mechanism(s) was allowed to develop for negating the influence of atrazine on gill in the longer exposure. Besides, differences in species of fish, developmental stage or other factors of rearing may also account for the nonidentity in the results. More profound decreases in the expressions of $\mathrm{Na}^{+}, \mathrm{K}^{+}$-ATPase mRNA were observed in kidney of female rare minnow in the present study. This could be supported by former reports of altered plasma ion levels in Atlantic salmon (Waring and Moore, 2004; Nieves-Puigdoller et al., 2007), Nile tilapia (Oreochromis niloticus) (Hussein et al., 1996) and catfish (Chrysichthyes auratus) (Hussein et al., 1996). However, the decrease of $\mathrm{Na}^{+}, \mathrm{K}^{+}$-ATPase mRNA was not statistically significant, and this difference might be related to the changed of renal tissues. $\mathrm{Na}^{+}, \mathrm{K}^{+}$-ATPase displayed high activity in the distal convoluted tubule and collecting tubes (Tuo et al., 2006), while changes of tubular parameters were only observed in females, though not significant in lower concentrations (data not shown). Anyway, both morphological and gene expression results suggested that females were more sensitive in response to HPA disruptors. This has been proved in vitro by McQuillan et al. (2003) who found that the interrenals from female chinook salmon and rainbow trout were more sensitive than those of males in response to external stimulations. Above all, the suppressed expressions of $\mathrm{Na}^{+}, \mathrm{K}^{+}$-ATPase indicated osmoregulatory disturbances in both gill and kidney of rare minnow, and $\mathrm{Na}^{+}, \mathrm{K}^{+}$-ATPase gene could be used as potential biomarker for AHs-disruptors.

There is a large body of researches in support of a physiological role for cortisol signaling involved in osmoregulation (McCormick, 2001). In vitro studies found that atrazine might affect the secretion of cortisol in adrenocortical steroidogenic cells of rainbow trout (Bisson and Hontela, 2002). However, the effects of atrazine on the receptor GR have been rarely studied. In the present study, gill gr mRNA was not significantly affected by atrazine exposure. Moreover, the expressions of $h s p 70$ and $h s p 90$ mRNA in gill were neither significantly changed. These results conformed previous presume that compensatory mechanism(s) other than GR signaling was allowed to develop for negating the influence of atrazine on gill after exposed to atrazine for 28 days. In the kidney the receptor transcripts were significantly decreased in females and significantly increased in males. Considering that significant alter- ations of $\mathrm{Na}^{+}, \mathrm{K}^{+}$-ATPase transcripts were only observed in kidney of females, we suppose that the translation mechanism of $g r$ was inhibited in males. Different expression patterns of $g r$ signaling and $\mathrm{Na}^{+}, \mathrm{K}^{+}$-ATPase between male and female rare minnow might be related with the sexual system. Zhang et al. (2008) have reported sex specific modulating mode of estrogen receptors (ER) in rare minnow exposed to 2,4-dichlorophenol. Nowak et al. (1995) have proved that sex steroids (estradiol and testosterone) could directly affect the adrenocortical secretion in rats. McQuillan et al. (2003) conformed these results in interrenal tissue of chinook salmon and rainbow trout, and also found that the interrenals of female fish were more sensitive than those of males in response to external stimulations. Above all, different controlling mechanisms of the sexual system might contribute to sexually dimorphic responses of the GR signaling in rare minnow. However, the interactions between the sexual system and adrenal system need further studies.

The highly conserved family of heat shock proteins (HSPs) plays an important role in the cellular stress response process and could be induced by different kinds of stressors in fish (Pratt, 1993). HSP70 and HSP90, the most important of the family, have been proved to act together as the molecular chaperons of the glucocorticoid receptor to form a functionally active and stable heterocomplex (Pratt, 1993).

The HSP70 is more likely to facilitate the binding of hormonebiding domain of GR to activate it (Pratt, 1993). In the present study, changes of gill hsp70 mRNA were not statistically significant. However, the differences in profiles of gill $g r$ and $h s p 70$ m RNA expressions at $3 \mu \mathrm{g} / \mathrm{l}$ atrazine treatment in females and all treatments in males may indicate a disturbance of the binding of GR and HSP70 in GR signaling pathway. In kidney hsp70 mRNA were significantly suppressed in females, and were significantly promoted in males. These sex specific changes of $h s p 70$ mRNA in kidney were consist with those of $g r$ mRNA, and this could be another proof of sex specific controlling mechanism of GR signaling. Up-regulations of $h s p 70$ in response to environmental stress have been reported in ovary, liver and gill of fish (Vijayan et al., 2000). In vitro and in vivo studies showed that elevated levels of cortisol suppressed heat stress-induced increases in hsp70 mRNA expression and protein levels in liver and gill in rainbow trout (Vijayan et al., 2000). These results indicated the possibility that hsp70 up-regulation might be a mechanism for increasing the stress threshold and enhancing self-protection (Vijayan et al., 2003). Therefore the changes of hsp70 levels in the present study indicated a disturbance of the GR signaling in rare minnow by atrazine exposure.

In addition to conformationally competent for ligand binding, the key role of HSP90 is to increase the stability of the heterocomplex by preventing proteasomal degradation of GR (Segnitz and Gehring, 1997). So HSP90 is crucial for cortisol mediated cellular action, including GR signal transduction (Pratt, 1993). Studies have shown that reduced HSP90 levels impaired steroid action (Picard et al., 1990). In vitro and in vivo studies demonstrated that stressors, including heat shock (HS) and osmotic stress altered hsp90 mRNA expressions in chinook salmon (Oncorhynchus tshawytscha) (Palmisano et al., 2000) and Atlantic salmon (Pan et al., 2000). In the present study, hsp90 mRNA was significantly suppressed in kidney of both male and female rare minnow. We suppose that the effects of atrazine on $g r$ signaling are mainly due to reducing the stability of the heterocomplex by suppressing the expression of hsp90.

Therefore, disturbance on osmoregulation of rare minnow could register as alterations in expressions of $\mathrm{Na}^{+}, \mathrm{K}^{+}$-ATPase, $\mathrm{gr}, \mathrm{hsp} 70$ and $h s p 90$. In addition, these results showed that renal tissue is more sensitive than gill in molecular response to environmental stress, and sex specific regulatory mechanisms should be considered in further studies. 


\section{Conclusions}

In conclusion, exposure to environmentally relevant concentrations of atrazine could result in obvious histopathological lesions in gill and kidney, and alterations of $\mathrm{Na}^{+}, \mathrm{K}^{+}$-ATPase, gr, hsp70 and hsp90 gene expressions in renal tissue of rare minnow. The alterations of these genes could cause disturbance on osmoregulation of rare minnow. Therefore, genes of $\mathrm{Na}^{+}, \mathrm{K}^{+}$-ATPase, gr, hsp70 and hsp90 could be used as potential biomarkers to screen AH disruptors.

\section{Acknowledgements}

This work was supported by the National Natural Science Foundation of China (20737003, 20877089) and National High-Tech Program of China (2006AA06Z424).

\section{References}

Alazemi, B.M., Lewis, J.W., Andrews, E.B., 1996. Gill damage in the freshwater fish Gnathonemus petersii (family: Mormyridae) exposed to selected pollutants: an ultrastructural study. Environ. Technol. 17, 225-238.

Bisson, M., Hontela, A., 2002. Cytotoxic and endocrine-disrupting potential of atrazine, diazinon, endosulfan, and mancozeb in adrenocortical steroidogenic cells of rainbow trout exposed in vitro. Toxicol. Appl. Pharm. 180, 110-117.

Cengiz, E.I., 2006. Gill and kidney histopathology in the freshwater fish Cyprinus carpio after acute exposure to deltamethrin. Environ. Toxicol. Pharmacol. 22, 200-204.

Colombea, L., Fostiera, A., Burya, N., Pakdelb, F., Guiguena, Y., 2000. A mineralocorticoid-like receptor in the rainbow trout, Oncorhynchus mykiss: cloning and characterization of its steroid binding domain. Steroids 65, 319-328.

Cooper, R.L., Stoker, T.E., Tyrey, L., Goldman, J.M., McElroy, W.K., 2000. Atrazine disrupts the hypothalamic control of pituitary-ovarian function. Toxicol. Sci. 53, 297-307.

de Renzis, G., Bornancin, M., 1984. Ion transport and gill ATPases. In: Hoar, W.S. Randall, D.J. (Eds.), Fish Physiology, XB. Academic Press, New York, pp. 65-104.

Dong, L., Chen, L., Li, Z., Gao, H., Li, J., 2006. Quality assurance/quality control for monitoring and analysis of trace triazines in water. J. Saf. Environ. 6, 35-38.

Freeman, J.L., Rayburn, L.A., 2004. Developmental impact of atrazine on metamorph in Xenopus laevis as revealed by nuclear analysis and morphology. Environ. Toxicol. Chem. 24, 1648-1653.

Hincapie, M., Maldonado, M.I., Oller, I., 2005. Solar photocatalytic degradation and detoxification of EU priority substances. Catal. Today 101, 203-210.

Huber, W., 1993. Ecotoxicological relevance of atrazine in aquatic systems. Environ. Toxicol. Chem. 12, 1865-1881.

Hussein, S.Y., El-Nasser, M.A., Ahmed, S.M., 1996. Comparative studies on the effects of the herbicide atrazine on freshwater fish Oreochromis niloticus and Chrysichthyes auratus at Assiut, Egypt. Bull. Environ. Contam. Toxicol. 57, 503-510.

Kokolakis, G., Panagis, L., Stathopoulos, E., Giannikaki, E., Tosca, A., KrügerKrasagakis, S., 2008. From the protein to the graph: how to quantify immunohistochemistry staining of the skin using digital imaging. J. Immunol. Methods 331, 140-146.

Li, W., Zha, J., Li, Z., Yang, L., Wang, Z., 2009. Changes of thyroid hormone levels and related gene expression in Chinese rare minnow (Gobiocypris rarus) during 3-amino-1,2,4-triazole exposure and recovery. Aquat. Toxicol. 92, 50-57.

McCormick, S.D., 2001. Endocrine control of osmoregulation in teleost fish. Am. Zool. 41, 781-794.

McCormick, S.D., Regish, A., O’Dea, M.F., Shrimpton, J.M., 2008. Are we missing a mineralocorticoid in teleost fish? Effects of cortisol, deoxycorticosterone and aldosterone on osmoregulation, gill $\mathrm{Na}^{+}, \mathrm{K}^{+}$-ATPase activity and isoform mRNA levels in Atlantic salmon. Gen. Comp. Endocrinol. 157, 35-40.

McQuillan, H.J., Lokman, P.M., Young, G., 2003. Effects of sex steroids, sex, and sexual maturity on cortisol production: an in vitro comparison of chinook salmon and rainbow trout interrenals. Gen. Comp. Endocrinol. 133, 154-163.

Meissner, W.A., Diamandopoulos, G.T., 1977. Neoplasia. In: Anderson, W.A.D., Kissane, J.M. (Eds.), Pathology. The CV Mosby Co., St. Louis, pp. 640-691.
Moore, A., Scott, A.P., Lower, N., Katsiadaki, I., Greenwood, L., 2003. The effects of 4nonylphenol and atrazine on Atlantic salmon (Salmo salar L.) smolts. Aquaculture 222, 253-263.

Nie, A.Y., McMillian, M., Parker, J.B., Leone, A., Bryant, S., Yieh, L., Bittner, A., Nelson, J., Carmen, A., Wan, J., Lord, P.G., 2006. Predictive toxicogenomics approaches reveal underlying molecular mechanisms of nongenotoxic carcinogenicity. Mol. Carcinog. 45, 914-933.

Nieves-Puigdoller, K., Björnsson, B.T., McCormick, S.D., 2007. Effects of hexazinone and atrazine on the physiology and endocrinology of smolt development in Atlantic salmon. Aquat. Toxicol. 84, 27-37.

Nowak, K.W., Neri, G., Nussdorfer, G.G., Malendowicz, L.K., 1995. Effects of sex hormones on the steroidogenic activity of dispersed adrenocortical cells of the rat adrenal cortex. Life Sci. 57, 833-837.

Palmisano, A.N., Winton, J.R., Dickhoff, W.W., 2000. Tissue specific induction of HSP90 mRNA and plasma cortisol response in chinook salmon following heat shock, seawater challenge, and handling challenge. Mar. Biotechnol. 2, 329-338.

Pan, F., Zarate, J.M., Tremblay, G.C., Bradley, T.M., 2000. Cloning and characterization of salmon hsp90 cDNA: upregulation by thermal and hyperosmotic stress. J. Exp. Zool. 287, 199-212.

Pratt, W.B., 1993. The role of heat shock proteins in regulating the function, folding, and trafficking of the glucocorticoid receptor. J. Biol. Chem. 268, 21455-21458.

Picard, D., Khursheed, B., Garabedian, M.J., Fortin, M.G., Lindquist, S., Yamamoto, K.R., 1990. Reduced levels of hsp90 compromise steroid receptor action in vivo. Nature 348, 166-168.

Ren, J., Jiang, K., Zhou, H., 2002. The concentration and source of atrazine residue in water of guanting reservoir. Environ. Sci. 23, 126-128.

Richards, J.G., Semple, J.W., Bystriansky, J.S., Schulte, P.M., 2003. Na+/K+-ATPaseisoform switching in gill of rainbow trout (Oncorhynchus mykiss) during salinity transfer. J. Exp. Biol. 206, 4475-4486.

Roberts, R.J., 1978. Fish Pathology. Bailliere Tindall, London.

Roy, S., Bhattacharya, S., 2006. Arsenic-induced histopathology and synthesis of stress proteins in liver and kidney of Channa punctatus. Ecotoxicol. Environ. Saf. $65,218-229$.

Schwaiger, J., Spieser, O.H., Bauer, C., 2000. Chronic toxicity of nonylphenol and ethinylestradiol: haematological and histopathological effects in juvenile Common carp (Cyprinus carpio). Aquat. Toxicol. 51, 69-78.

Segnitz, B., Gehring, U., 1997. The function of steroid hormone receptors is inhibited by the hsp90-specific compound geldanamycin. J. Biol. Chem. 272, 18694-18701.

Tuo, Y., Zhang, Y., Li, P., Yin, J., 2006. Histological observations on urinary system of Sinilabeo rendahli kimurai. Sichuan J. Zool. 25, 116-120.

U.S. EPA, 2002. Reregistration Eligibility Science Chapter for Atrazine Environmental Fate and Effects Chapter. Washington, DC, USA

Velisek, J., Wlasow, T., Gomulka, P., Svobodova, Z., Dobsikova, R., Novotny, L., Dudzik, M., 2006. Effects of cypermethrin on rainbow trout (Oncorhynchus mykiss). Vet. Med. 51, 469-476.

Vijayan, M.M., Raptis, S., Sathiyaa, R., 2003. Cortisol treatment affects glucocorticoid receptor and glucocorticoid-responsive genes in the liver of rainbow trout. Gen. Comp. Endocrinol. 132, 256-263.

Vijayan, M.M., Campbell, T., Strutt, E., Sathiyaa, R., 2000. Cortisol modulates heat shock protein expression in primary cultures of rainbow trout hepatocytes. In: Proceedings, 4th International Symposium on Fish Endocrinology, Seattle, WA.

Wang, J.W., 1992. Reproductive biology of Gobiocypris rarus. Acta Hydrobiol. 16, 165-174.

Waring, C.P., Moore, A., 2004. The effect of atrazine on Atlantic salmon (Salmo salar) smolts in fresh water and after sea water transfer. Aquat Toxicol 66, 93-104.

Wendelaar Bonga, S.E., 1997. The stress response in fish. Physiol. Rev. 77, 591625.

Wolf, J.C., Dietrich, D.R., Friederich, U., Caunter, J., Brown, A.R., 2004. Qualitative and quantitative histomorphologic assessment of fathead minnow (Pimephales promelas) gonads as an endpoint for evaluating endocrine-active compounds: a pilot methodology study. Toxicol. Pathol. 32, 600-612.

Zaroogian, G., Gardner, G., Horowitz, B.D., Gutjahr-Gobell, R., Haebler, R., Mills, L. 2001. Effect of 17b-estradiol, o, $\mathrm{p}^{\prime}$-DDT, octylphenol and p, $\mathrm{p}^{\prime}$-DDE on gonadal development and liver and kidney pathology in juvenile male summer flounder (Paralochthys dentatus). Aquat. Toxicol. 54, 101-112.

Zha, J., Wang, Z., Wang, N., Ingersoll, C., 2007. Histological alternation and vitellogenin induction in adult rare minnow (Gobiocypris rarus) after exposure to ethynylestradiol and nonylphenol. Chemosphere 66, 488-495.

Zhang, X., Zha, J., Li, W., Yang, L., Wang, Z., 2008. Effects of 2,4-dichlorophenol on the expression of vitellogenin and estrogen receptor genes and physiology impairments in Chinese rare minnow (Gobiocypris rarus). Environ. Toxicol. 23, 694-701. 